\title{
Factors Affecting Students' Achievement in English Language Learning
}

\author{
Assoc. Prof. Dr. Abdallah Hussein El-Omari
}

Irbid University College, Al-Balqa Applied University, Jordan d.abdullah.amri@gmail.com

\section{Doi:10.5901/jesr.2016.v6n2p9}

\begin{abstract}
This article investigates the effect that some factors would have on the achievement of students learning English as a foreign language. Secondary school students' grades of the first semester 2013 / 2014 in English have been used as parameter of achievement. The factors (attitudinal, social, socioeconomic, and extracurricular) which are believed to influence students' achievement have been included in a 16 item yes / no questionnaire. Findings show that there is significant relationship between the factors and students' achievement in English language learning.
\end{abstract}

Keywords: factors, language, learning, English, achievement

\section{Introduction}

Learning English involves many factors that would affect the process of learning positively or negatively. This article is concerned about four factors which are believed to have a prominent relationship with learning English in Jordan and many Arab countries (Mukattash, 1980). A 'yes' or 'no' question questionnaire is used to detect the effect that certain factors would have on the achievement of Jordanian secondary schools students in English. Study subjects were requested to respond to the 16 items about the various factors that might affect students' achievement in English as a scheduled school curricular subject. The questionnaire items will be categorized into four main factors: attitudinal, socioeconomic, social, and extra-curricular. In his study about language proficiency in Jordan, Mukattash (1980) studies the relationship between factors and students achievement in the secondary stage. It is hoped that this present study will find some sort of relationship amongst the factor items and subjects' achievement at learning English language.

\subsection{Literature Review}

Factors affecting school students' language learning achievement has been the concern of socio-linguists and educationist since the last quarter of the twentieth century. Ramirez, (1986) conducted a study on students in a small rural school taught by the same teacher. It was found that the communicative abilities of students in the rural school were lower than those in urban schools. Moreover, urban school students produced more descriptions and speech acts. The issue has gained more interest with the beginning of the twenty first century. Genc and Aydin (2011) examined some factors affecting the motivation level of the preparatory school students in using a web-based computer-assisted language-learning course. The sample group of the study consisted of 126 English-as-a-foreign-language learners at a preparatory school of a state university. It was found that there were no statistical differences between such selected demographic variables as learners' age, gender, grades, compulsory and optional status, type of high school, parents' educational status, the period of the participants' language-learning process, and experience of computer use. The only variable found to be statistically significant was the degree of importance of learning English for the participants; more than half the participants possess moderately high motivation level. Jurkovic (2010) examined the effect of two factors on achievement test scores in English as a foreign language for specific purposes in higher education: preexisting linguistic competence and frequency of use of language learner strategies. The results of this study indicated a statistically significant positive effect of general linguistic competence on achievement test scores. Among the constructs of language learner strategies, however, the only construct having a statistically significant effect on achievement test scores was metacognitive strategies. Suh et al (2010) investigated the effectiveness of massive multiplayer online roleplaying game (MMORPG)-based (massive multiplayer online role-playing game) instruction in elementary English education. The results indicated that students studying English utilizing online role-playing games showed higher scores in areas of listening, reading, and writing than those who attended face-to-face instruction classes. It was also found that 
prior knowledge, motivation for learning, and network speed were factors affecting achievement in English learning. Hungi and Thuku (2010) employed a multilevel analysis procedure in order to examine the pupil and school levels factors that contributed to variation in reading achievement among Grade 6 primary school pupils in 14 southern African school systems. The most important factors affecting variation in pupil achievement across most of these school systems were grade repetition, pupil socioeconomic background, speaking the language of instruction at home, and pupil age. South Africa, Uganda and Namibia were among the school systems with the largest between-school variation while Seychelles and Mauritius had the largest within-school variation. Low social equity in reading achievement was evident in Mauritius, Seychelles and Tanzania. Small (2010) reported that children whose parents are involved with their education tend to perform better in school. Students demonstrate higher academic and behavior levels, have higher aspirations, and display other positive school behaviors when parents are knowledgeable, encouraging, and involved. It is agreed that parental involvement can positively impact student achievement in urban schools. Findings indicate that two significant factors affecting parents' active involvement are the time school events or interactions are scheduled, and direct communication from the school, such as personal invitations to attend events. The study also identifies effective strategies to increase parental involvement applicable to similar urban school settings. Woo (2009) investigated the multiple factors affecting English language learners' (ELLs) low reading achievement in standardized tests by exploring the complex, hierarchical relation in student, classroom, and school levels. Specifically, this study (a) identified the impact of student-, teacher-, and school characteristics on ELLs and non-ELLs' standardized reading achievement and (b) examined how these characteristics impact on their reading achievements differently for ELLs and non-ELLS. The HLM (hierarchical linear modeling) analyses determined that some factors were related to ELLs' and non-ELLs' reading achievement differently after controlling for student, teacher, and school variables. Specifically, the frequency of a language other than English spoken at home yielded different results for ELLS and non-ELLS. The frequency of a language other than English spoken at home was a significant, positive predictor of reading achievement for ELLs. Meanwhile, it was a non-significant, negative predictor for non-ELLS. Positive influence of the frequent uses of a language other than English at home on ELLs' reading performance implied a positive effect of first-language speaking on ELLs' reading. Another implication that this study brought was the importance of providing equal opportunity to learn to all students. Huang and Brown (2009) discussed the cultural factors that affect Chinese students' academic learning at North American universities. They found that university classrooms are failing to meet the educational expectations of Chinese students. Students mentioned six areas where they feel discomfort: (1) They feel uncomfortable with the classroom behavior of North American students; (2) They question the value of a professorial focus on discussion rather than lecture; (3) They query the professor's failure to follow the textbook; (4) They feel there is too much emphasis on group work; (5) They note a lack of lecture summaries along with an apparent lack of organization; and (6) They share no common interests (e.g. sports, religion) with their North American counterparts. Harb and El-Shaarawi (2007) found that the most important factor which affected student performance was their competence in speaking English. The sample was a group of 864 business and economics students in The United Arab Emirates. The authors used regression analysis for the study. The results of the study showed that students who participated in class discussions and who were on leave from their jobs outperformed other students. Missing many lectures and living in a crowded household negatively affected student performance. The results of the study also showed that non-national students outperformed national students, and female students outperformed their male counterparts. Helm (2007) reviewing several related research suggested that if a model could be developed to guarantee student success it would include a teacher who: (1) is highly qualified; (2) possesses the proper teaching license for their area; (3) possesses the dispositions of caring and empathy; (4) has a strong work ethic and critical thinking ability; (5) has supportive classroom parents; (6) has an eighteen to one pupil-teacher ratio; and (7) has adequate funding. Kang (2006) examined factors that affected a Korean physician's learning and use of ESL in an English-speaking country. Data from interviews, observations, notebook memos and e-mails were used. The findings indicated that individual factors: personality (perfectionism and extroversion), occupation, beliefs, and motivation, and social-contextual factors: lack of contact with native speakers and insecurity about speaking English in the presence of other Koreans, influenced the participant's learning and use of ESL. The findings also revealed that the participant's motivation and extroversion played a role in overcoming the socialcontextual obstacles limiting learning opportunities, which illustrates interactions between individual and social-contextual factors. In another study, Aduwa-Ogiegbaen and lyamu (2006) examined the factors responsible for the poor quality of the teaching of English as a second language in public secondary schools across the six geopolitical zones in Nigeria. Three thousand senior secondary school students were asked to respond to a questionnaire consisting of three variables: (1) Frequency of the use of instructional media; (2) Frequency of the use of instructional techniques; and (3) The school learning environment. Results revealed that English language teachers do not frequently use modern 
instructional technologies and variety of teaching techniques in their English language lessons. It was also found that students learn under harsh environment, which is often rowdy, congested and noisy. Lamb et al (2006) provided an overview of the major factors and interventions affecting migrant students' academic performance/outcomes. Factors outside the school, such as poverty, family, and English language proficiency, are discussed. Next, factors inside the school, such as student records, credit accrual, and school curriculum, will be reviewed. May et al (2006) carried out a study with students and staff from a college of further education in south London. The college has a mix of male and female students from a range of ethnic groups, the largest of which is white British. In this article the qualitative findings from data on the experiences and perceptions of the staff and full -time students are discussed in the context of the variable completion and achievement rates of the students and results from other studies. The main themes linked to ethnicity, gender, completion and achievement emerging from the analysis indicate broad agreement between students and staff over issues around learning and teaching and written and spoken English; however, their particular perspectives led to their having differing views on the most important factors external to the college and those affecting student motivation. Abedi and Gandara (2006) studied the factors that contribute to the performance gap between subgroups and mainstream students. To understand and control for factors leading to the performance gap between subgroups and mainstream students one must clearly understand the issues specific to each subgroup. They focus on assessment and performance issues for English language learner (ELL) students as a subgroup. Identifying factors affecting the performance gap between ELL and non-ELL students may help gain insight into assessment issues for other subgroups of students as well as strengthen assessment of this group. Saeed, Gondal, and Bushra (2005) conducted a paper which aimed to focus on achievement level of primary grade students in different subjects taught at primary level and the factors affecting the student achievement in this regard. The instruments were: the achievement tests in three subjects mathematics, Urdu (national language) and life skills (Islamyat, social studies and science); and questionnaires for teachers and students to know various possible factors affecting achievement. Overall the performance of the female students was relatively better than their male partners. Location-wise, the rural students performed better than the urban students. Among the factors affecting students achievement were parental education, their occupation and guidance, teacher guidance, social status, transport facility, self study, book reading and home work--all have a positive or negative correlation with students' achievement. This paper is of use to those wishing to understand the achievement levels of students at primary grade in developing countries.

Andreou et al (2005) studied the affecting factors in second language learning. They investigated the influence of gender, among other factors, on the performance of phonological, syntactical and semantic tasks in L2. Females performed better than males in syntax and semantics which is explained by the general female superiority on verbal tasks based on differences in hemispheric specializations for language functions between the two sexes.

The factors cited in the literature this article reviews are mainly social, situational, socioeconomic, attitudinal, or extracurricular. The factors cover issues such as students' age, gender, grades, type or location of school. Student families' situation and position, parents' education status are also amongst the factors the literature reviews, as well as linguistic competence and frequency of use of language learner strategies. Students gain better achievement when utilizing online role-playing games than those who attended face-to-face instruction classes.

\subsection{Statement of the Problem}

There are generally factors which affect achievement positively or negatively. Realizing these factors and the relationship they have with the achievement might facilitate understanding, and help identifying what problems the achievement faces, so that solutions could be found and improvements be developed. English has always been a major problem that many Jordanian learners of English encounter. Some students would skip school because of their poor achievement in English. Sometimes they hinder the teaching-learning process in the classroom which usually ends in hating the English teacher and may be the whole school. English language teaching and learning process is affected by many factors and variables, mainly socioeconomic, extracurricular, and attitudinal. For example, it is widely believed that families first born children receive more attention and care from their parents; children whose parents are good at or speak English are usually good learners of English; and those who live in their own houses have a sense of stability and social security which help them learn better. Therefore, these issues need investigation since few studies focused on factors affecting students' achievement in English language learning (Oxford, 1989; LoCastro, 1994; Green and Oxford, 1995;; Embi, 2000; El-Omari, 2002). 


\subsection{Study Population and Sample}

Secondary school students learning English in Jordan are the population of this study. They are represented by the secondary school students of the First Directorate of Education in the Irbid Governorate, out of which the sample was randomly selected (see table 1 below). This directorate runs and supervises 57 secondary schools (31 female and 26 male) of 458 classrooms ( 245 female and 213 male), which provide schooling for about 13800 students (about 7400 female and about 6400 male) with an average of about 30 students per-classroom which can be considered a reasonable class size.

Table 1: Distribution of students out of which the sample was selected

\begin{tabular}{|l|c|c|c|}
\hline Gender & Number of schools & Number of classrooms & Number of students \\
\hline Male & 26 & 213 & 6400 \\
\hline Female & 31 & 245 & 7400 \\
\hline Total & 57 & 458 & 13800 \\
\hline
\end{tabular}

Out of the five hundred students who were asked to respond to the questionnaire, 496 students gave back their answers. This is about 3.6 percent of the total number of secondary school students in the First Irbid Governorate educational area which reasonably appears representing. Students were randomly selected by teachers of English at 20 of the 57 schools which is about $35 \%$ of all schools in the educational area mentioned above, (11 female and 9 male) with about 25 subjects at each school. The sample represents secondary school students of different educational streams (Academic and Vocational) and different geographical regions (urban and rural). However, these categorizations are not considered in the article. Instead, respondents' attitude for learning English, their families' economic levels, their position (being the first/eldest child) in their families, level of parents' education, and extra-curricular readings have been considered as categories of the sixteen yes / no item questionnaire. Students' grades of the first semester 2013 / 2014 are taken from their school grade records. For the purpose of research these grades are used to divide subjects into two main levels: A. $100-65$ good, and B. $64-00$ poor

\subsection{Reliability of the Questionnaire}

The researcher has developed the questionnaire used in this article as he used to be a teacher of English at the secondary stage for more than fifteen years. According to the cronbach alpha reliability coefficient criterion $(0.73)$, it has proved reliable.

\subsection{Study Objectives}

The study aims at finding a relationship between the four factors it is concerned about and students' achievement in English language learning. Improving the conditions and environments students live in and study according should help them learn better. Decision makers in educational and social issues have to consider these factors when they set policies and plans related to students learning in general and learning English in particular.

\subsection{Study Question}

This study tries to answer the following question:

Is there a relationship between achievement at learning English and the attitudinal, social, socioeconomic, and extracurricular factors among Jordanian secondary school students?

\section{Study Findings}

Employing the SPSS application, the Factor analysis ANOVA was used to analyze the data collected from subjects' responses on the questionnaire, the $(1-16)$ items of which appear in table 2 below. The table reflects the percentage and the means of the responses as well as the significant differences (if any). 
Table 2. ANOVA Analysis of Factor items across students' achievement (Good and Poor)

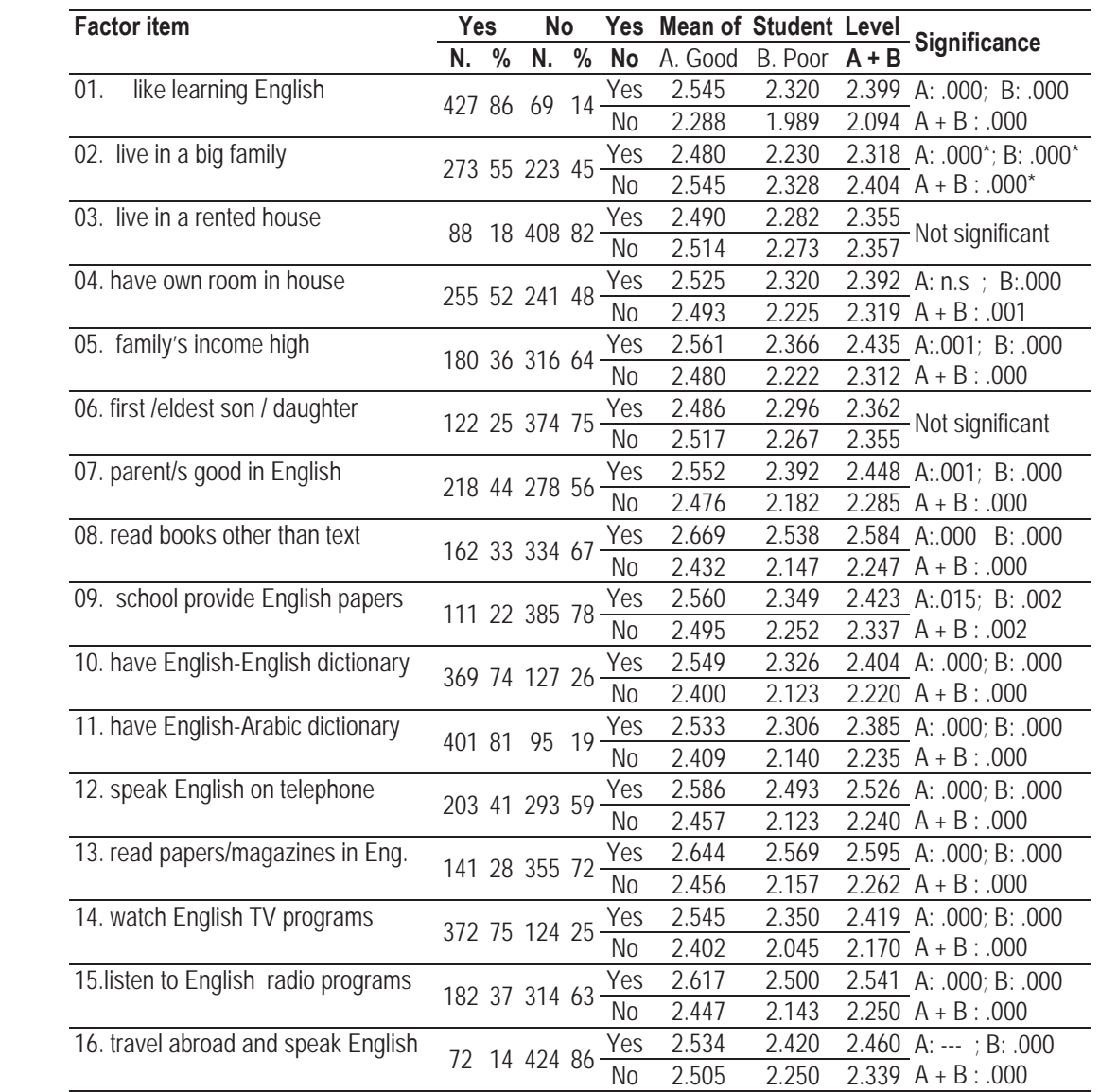

Note: * significant at 'No' answer

The statistical evidence tabulated in table 2 above shows the importance of studying the factors affecting English language learning achievement and learning English in general. The study covers attitudinal, social, socioeconomic, and extracurricular factors, which are cross-tabulated with the good and poor achievement of students at learning English language. Following are some broad generalizations:

- Students who like to learn English report greater achievement at learning English language than those who do not like to learn English.

- Small family students report greater achievement of English language learning than those of big families.

- Living in ones own house, or a rented one does not have an effect on the achievement of Jordanian secondary schools students at learning English language.

- Students having their own rooms in their houses report greater achievement of English language learning than those who do not have their own rooms.

- Students who think they belong to high-income families have higher achievement at learning English language than those who think they are of low income families.

- Being the first and / or the eldest child of a family does not affect students' achievement at learning English language.

- Students, whose parents or any of them are good at English, report greater achievement of English language learning than those whose parents are not. 
- Students who respond positively to English telephone calls report greater achievement of English language learning than those who respond negatively.

- Students who travel abroad, and have the chance to speak English there, report greater achievement of English language learning than those who do not travel.

- Students where schools provide English newspapers report higher achievement at English language learning than students whose schools do not provide English newspapers.

- Few schools provide English newspapers at school libraries for students and teachers.

- Students who read English newspapers / magazines report greater achievement at English language learning than students who do not.

- The majority of students (72\%) do not read English newspapers and /or magazines.

- Students who watch English TV programs report greater achievement at English language learning than students who do not.

- Reading extracurricular books enables learners to achieve better English language learning than the learners who only read the text books.

- Students who have and frequently use dictionaries (English - English and English - Arabic) report better English language learning than students who do not have dictionaries.

\subsection{Discussion of the Findings}

\subsubsection{Attitudinal Factor}

This includes one item, which is item 01- I like learning English. Table 2 shows 427 out of the 496 subjects say that they like learning English with the percentage of 86\%. Using ANOVA, the two categories of the level items (Good and Poor) and their overall achievement levels are all found to be significantly different $(p<0.000)$ for the student's positive attitude against their negative attitude to learning English with the means Good 2.545, 2.288, Poor 2.320, 1.989, and overall Good \& Poor 2.399, 2.094 respectively. This means that students willing to learn English score higher grades than those whose achievement is poor.

\subsubsection{Socioeconomic Factor}

This factor includes four items (2- live in a big family, 3- live in a rented house, 4- have own room in house, 5- family's income is high). These items represent $25 \%(4: 16)$ of all the factors. The first item in this category i.e. the socio economic factor, (02- live in a big family) is negatively significant with the two categories of achievement levels (good and poor) and their overall reported achievement. This means that students related to small families report better English language learning achievement than those living in big families (Good: 2.480, 2.545), (Poor: 2.230, 2.328), and the overall of (Good \& Poor $2.318,2.404) p<0.000$. A total of 273 students of the sample live in big families with the percentage of $55 \%$, while 223 subjects with $45 \%$ say that they live in small families. The second item (03. live in rented house) does not show any significant difference. This means that living in one's own house or a rented one does not have an effect on Jordanian secondary schools students' learning English achievement. Table 2 above shows that the majority of students (408 out of 496, 82\%) live in their own houses, which fosters the feeling of stability and social security. With the third item (04. have own room in house) about half of the students $(52 \%, 255 / 496)$ have their own rooms in their houses. Table 2 also shows positive significant difference for good students over poor students' achievement with the means $(2.525$ \& 2.493), (2.320 \& 2.225) and overall English learning achievement (2.392 \& 2.319) respectively. This means that students having their own rooms in their houses learn English better than those who do not have their own rooms, but at the same time both student factor categories, i.e. those who have their own rooms and those who do not, nearly achieve the same level of English language learning. The last item in the socio-economic factor in Table 2 involves family income. About $36 \%(180 / 496)$ of the subjects believe that their income is high. The table above shows secondary school students' achievement at learning English language. Students of high-income families report achieving higher grades at learning English than those of poor-income families and the overall achievement of both groups with the means $(2.561 \& 2.480)$, ( $2.366 \& 2.222)$ and $(2.435 \& 2.312)$ respectively (see the table for difference significance). This means that rich family children achieve better results than those who are not at learning English language at the secondary school level. This might be attributed to the affordability that rich families would provide to their children to have facilities and access devices of learning English. 


\subsubsection{Social Factor}

This factor consists of four items, which also make up 25\% (4/16). The first item (06-first/eldest son/daughter) does not have significant difference regarding secondary school students' achievement of English language learning. This means that being the first and / or the eldest child does not affect students' achievement of learning English. It was believed that parents give more care and concern to the first child. In the second item (07- parent(s) good at English) 44\% (218/496) of the subjects have (a) parent(s) who is /are good at English. The two categories of achievement items (i.e. Good \& Poor) as well as the overall of English learning achievement differ significantly with students whose parents are good at English with the means $(2.552,2.476),(2.392,2.182)$, and $(2.488,2.285)$, and the significant level is $p<0.001,0.000$ respectively. This means that student(s) whose parent(s) is/are good at English report greater achievement of language learning than students whose parents are not good at English. The third item of the social factor (12. speak English on the telephone) also differs significantly at English language learning achievement as well as the overall of students' achievement with the means $(2.586,2.457),(2.493,2.123)$ and $(2.526,2.240)$ respectively. This means that students who respond positively to English telephone calls report greater level of achievement at English language learning than those who respond negatively to English telephone calls. In fact, 41\% (203/496) of the subjects respond positively to telephone calls in English, which means that quite a good number of students are able to communicate in English on the phone. The last item of the social factors (16. travel abroad and speak English) differs significantly at the poor achievement of students' English language learning and the overall of achievement with the means $(2.420,2.250)$ and $(2.460,2.399)$ respectively. There is no significant relationship between traveling abroad and good students' achievement of English language learning. This means that students who travel abroad, and have the chance to speak English, report greater achievement of English language learning than those who do not travel. In fact only 14\% (72/496) of the subjects responded with "yes".

\subsubsection{Extracurricular Factor}

This includes seven items, which are about $44 \%(7 / 16)$ of the whole items. Four items out of the seven can be seen as media related factors (09- school provides English newspapers, 13 - read newspapers / magazines in English, 14- watch English TV programs, and 15- listen to English radio programs). The first item of which, i.e. item 9 differs significantly with both of the achievement categories (Good and Poor) and the overall of the two categories with the means (2.560, $2.495),(2.349,2.252)$, and $(2.423,2.337)$ respectively. This means that students where schools provide English newspapers report greater achievement of English language learning by good and poor students than students whose schools do not provide English newspapers. In fact, not many schools provide English newspapers; only 22\% (111 / 496) of the subjects report that their schools do so. The second item (13. read newspapers / magazines in English) reflects a strong significant difference with the two achievement categories, Good and Poor, and the overall achievement levels with the means $(2.644,2.456),(2.569,2.15)$, and $(2.595,2.262)$ respectively. This also shows that students who read English newspapers / magazines report greater achievement of English language learning than students who do not. Unfortunately, the majority of students $(72 \%, 355 / 496)$ do not read English newspapers and /or magazines. Similarly the third item (14. watch English TV programs) differs significantly with English language learning achievement by good and poor students as well as the overall achievement levels with the means $(2.545,2.402),(2.35,2.045)$, and $(2.419,2.170)$ respectively. This is an indication that students who watch English TV programs report greater achievement of English language learning by the two student categories of good and poor than those who do not. The figures here might be misleading because the majority of the subjects ( $75 \%$ or 372 / 496) who watch TV programs are only motivated by the desire to see the pictures. However, unconscious learning would take place through matching what they hear of the English dialogues and talks and what they read in the translation. The last item in the media related sub-factor (15. listen to English radio programs) shows a strong significant difference with the English language learning achievement by the good and poor students and their overall achievement levels as well. This is clearly displayed in the means the table above shows $(2.617,2.447),(2.500,2.143)$, and $(2.541,2.250)$ respectively. This shows that students who listen to English radio programs are better learners of English regardless of the grades they would obtain in the English school course than students who do not listen. With the spread of visual media, it looks satisfactory to have this percentage of subjects (37\%, 182 / 496) who listen to English radio programs.

The other sub-set of the extracurricular factor items deal with using academic materials such as books and dictionaries, which play a crucial role in language learning. The first item in this set (8. read books other than text books) shows a high significant difference with the English language learning achievement by good and poor students, as well 
as the overall achievement by the two student categories with the means $(2.669,2.432),(2.538,2.147)$, and $(2.584$, 2.247) respectively. Nearly one third of the subjects (33\% or $162 / 496)$ read books other than the textbooks. Considering the means mentioned above, it can be understood that reading books outside the curriculum enables good and poor learners of English to have greater achievement of English language learning than the learners who only read the textbooks. The second and third items (10. have an English - English dictionary and 11. have an English - Arabic dictionary) deal with learning new words. The two items show significant difference for using dictionaries with English language learning achievement by good and poor students as well as the overall of both student categories. The means of the two items in Table $1(2.549,2.400),(2.326,2.123)$, and $(2.404,2.220)$ for item 10, and $(2.533,2.409),(2.306$, $2.140)$, and $(2.385,2.235)$ for item 11 respectively, indicate that students who have dictionaries report greater achievement of English language learning. The achievement with both, good and poor students having dictionaries is higher than those who do not have dictionaries. Most subjects have dictionaries (74\% or 369/496 have English - English dictionaries and 81\%, 401/496 have English - Arabic dictionaries). This study shows that English language learning achievement is affected by many factors, which foreign language teachers and learners should be aware of.

\section{Recommendations}

This study shows that secondary school students' achievement at learning of English as a foreign language is clearly affected by different factors. The aptitude to learn English as a foreign language is high. This is realized form the high status which English has obtained in most walks of life. English has become a necessity to excel in science and technology and to catch up with the ever developing discoveries and inventions. Policy makers are called upon to take care of the welfare of individuals and societies whose lives are strongly affected by modern life requirements where English is the main means of communication (this does not mean neglecting the role Arabic has in this regard). The four factors this article investigates are closely related to the learning of English as a foreign language. Therefore, improving the environment to raise learners' achievement at learning English should receive more attention from educationists and linguists. Public and private sectors are called upon to work hand in hand to take care of English language university graduates to excel in using English by providing English departments at universities with English language learning facilities and organize activities in which English is the medium language. The same could be done at schools for more contact and communication in English.

\section{References}

Abedi, J. ; Gandara, P, 2006, Performance of English Language Learners as a Subgroup in Large-Scale Assessment: Interaction of Research and Policy Educational Measurement: Issues and Practice, 25, 4, 36-46

Aduwa-Ogiegbaen, S. E.; Iyamu, E. O. S., 2006, Factors Affecting Quality of English Language Teaching and Learning in Secondary Schools in Nigeria, College Student Journal, 40, 3, 495 - 504

Andreou, G.; Vlachos, F.; Andreou, E., 2005, Affecting Factors in Second Language Learning, Journal of Psychological Research, 34, 5, $429-438$

El-Omari, A. H., 2002. Language Learning Strategies Employed by Jordanian School Learners learning English as a Foreign Language, unpublished PhD Thesis, Faculty of Education, National University of Malaysia (UKM), Bangi, Malaysia

Embi M. A., 2000. Language learning strategies: a Malaysian context, Faculty of Education, Universiti Kebangsaan Malaysia

Genc, G.; Aydin, S. 2011, Students' Motivation toward Computer-Based Language Learning, International Journal of Educational Reform, 20, 2, 171-189

Green. J.M. \& Oxford, R. 1995. A closer look at learning strategies, L2 proficiency, and gender, TESOL Quarterly, 29, 2, 261-297.

Harb, N.; El-Shaarawi, A. 2007, Factors Affecting Business Students' Performance: The Case of Students in United Arab Emirates, Journal of Education for Business, 82, 5, $282-290$

Helm, C. 2007, Teacher Dispositions Affecting Self-Esteem and Student Performance, Clearing House: A Journal of Educational Strategies, Issues and Ideas, 80, 3, 109-110

Huang, J. and Brown, K. 2009, Cultural Factors Affecting Chinese ESL Students' Academic Learning, Education, 129, 4, 643 - 653

Hungi, N., Thuku, F. W. 2010, Variations in Reading Achievement across 14 Southern African School Systems: Which Factors Matter? International Review of Education, V. 56, N. 1, pp. 63-101

Jurkovic, V. 2010, Language Learner Strategies and Linguistic Competence as Factors Affecting Achievement Test Scores in English for Specific Purposes, TESOL Journal, 1, 4, 449-469

Kang, Su-Ja, 2006, Individual and Social-Contextual Factors Affecting the Learning and Use of ESL: A Case Study of a Visiting Korean Physician, TESL Canada Journal, 129, 4, $643-653$

Kouraogo, P. 1993. Language learning strategies in input-poor environment. System, 21, 2, 165-173.

Lamb, G. D.; Ochoa, S. H.; De Alba, R. G., 2006, Issues and Interventions Influencing the Academic Outcomes for Migrant Students, 
Multiple Voices for Ethnically Diverse Exceptional Learners, 9, 1, 135-148

LoCastro, V. 1994. Learning strategies and learning environments. TESOL Quarterly, 28, 2, 409-414.

May, S.; Bidgood, P.; Saebi, N. 2006, Are They Thinking What We're Thinking?: College Staff and Student Perceptions of the Impact of Ethnicity and Gender on Completion and Achievement at a College of Further Education, Journal of Further and Higher Education, 30, 3, 243-254.

Mukattash, L. 1980. English language proficiency in Jordan: educational socio-economic and other factors. Human Studies Magazine, Jordan University, 72, 7-31.

Oxford, R. 1989.Use of language learning strategies: a synthesis of studies with implications for strategy training. System, Issue: 17, pp. 1-13.

Oxford, R. 1994. Language learning strategies: an update, ERIC Digest, Office of Educational Research and Improvement (ED), Washington, D.C.

Ramirez, A.G. 1986. Language learning strategies used by adolescents studying French in New York schools, Foreign Language Annals, 19, 2, 131-141.

Saeed, M. , Gondal, M. B. , Bushra, 2005, Assessing Achievement of Primary Grader Students and Factors Affecting Achievement in Pakistan, International Journal of Educational Management, 19, 6, 486-499.

Small, La'Quetta S., 2010, Parental Involvement in an Urban School Setting, cbmcbMProQuest LLC, Ed.D. Dissertation, Rowan University.

Suh, S.; Kim, S. W.; Kim, N. J., 2010, Effectiveness of MMORPG-Based Instruction in Elementary English Education in Korea, Journal of Computer Assisted Learning, 26, 5, 370-378.

Woo, Hui-Jeong, 2009, Investigation on Multiple Factors Affecting English-Language Learners' Reading Achievement: Hierarchical Linear Modeling Approach ProQuest LLC, Ph.D. Dissertation, University of Illinois at Urbana-Champaign 
